Archived version from NCDOCKS Institutional Repository http://libres.uncg.edu/ir/asu/

\author{
Appalachǐan \\ B O O NE, NORTH CAROLINA

\section{Oh Boy Comics! A Reflexive Ethnography of Comics and Childhood}

\author{
By: Victoria Grube
}

\begin{abstract}
This is a reflexive ethnography that interweaves a 1960s Midwest childhood with the culture of comic books and a critique of the 1960s and the nuclear family. My comic choices were more eclectic than my brother's vast collection of Marvel, but both of us found in comics an escape from a strained childhood. The comic books, like all art, held meanings that were deeper than the pamphlet's face value. What did this art form do for us? Certainly entertained, but even more. Becoming immersed in the lives of the characters, we were not alone. We lived lives balancing eggs on spoons, and we collected little pictured stories that offered clearer insights about family life than what the world was telling us.
\end{abstract}

Grube, Victoria (2010) "Oh Boy Comics: A Reflective Ethnography." Cultural Studies / Critical Methodologies 10, no. 1 (2010). The online version of this article can be found at: http://csc.sagepub.com/content/10/3/238 originally published online 22 March 2010 [DOI:10.1177/1532708609359512] 


\section{Oh Boy Comics! A Reflexive Ethnography of Comics and Childhood}

Steamy Midwest summers led to my early love of comic books. In the 1960s, most homes were cooled by electric fans or the occasional window air conditioner, so we found relief at Bogards Drug Store, a corner pharmacy that offered icy bottled pop, three circular racks of comics, and a cold linoleum floor. Daily, my brother Scott and I escaped suffocating temperatures by pedaling three blocks to Bogards where we would put our dimes into slots and slide frosty bottles of Nehi Grape through the narrow chutes of the soda dispenser. The hinged metal portals would relax as we pulled upwards on the bottle, releasing a snowy glass drink into our hands.

Comics, at the time, were ten, twelve or fifteen cents; annuals were twenty-five; and we would pore over the latest Beetle Bailey, Archie, Hulk, Fantastic Four, or Little Lulu. Tubby and Lulu's lives were like squeak toys, uncomplicated and cracked me up. The adults were harmless and forgiving. Archie had shallow encounters with dating, fashion, high school, cars, rivalry, and parents. The ongoing love triangle between Archie, Betty, and Veronica was goofy, Veronica and Betty were identical except for hair color. Nothing serious ever happened in Riverdale. Breasts and dating seemed as innocuous as hamburgers and jalopies.

With soda bottle drained, I paid for my favorite issue, and the cosmetics clerk slid it into a putty colored paper sack. Scott had a paper route so he bought every new Marvel issue: Fantastic Four, Thor, Spiderman, and The Incredible Hulk. My parents worried over Scott's avid reading of comics, so entering the house he hid new issues under his shirt. Scott shared my comic craze. He was obsessed with Marvel comics. He bought plastic covers for early issues and stored tall stacks of comics along the basement wall, sorting comics by hero and by release date.

My brother always leaned into the wind. He was the first to plunge through bushes, to ride a bike no handed, and at age three to hurtle a small stool across the room. At age ten, Scott bought a diamond needle for his record player with the accompanying brochure picturing a tow truck and slogan "A worn needle is a record wrecker," insisting that needles needed replacing after 2,000 albums. Scott taped a square of paper above the turntable and checked each time he played a record. The wall filled with check sheets. After three years, a new needle was purchased.

Scott, was a Marvel fan claiming DC comics, like Superman, Justice League of America, The Flash, Green Lantern, and Batman, were too moralistic. Scott was absorbed with Marvel's Fantastic Four, a family of superheroes armed with earth, air, fire, water, invisibility, and spandex. The Thing, the gruff but lovable Fantastic Four uncle figure, was his hero. On the school blacktop, Scott battled adversaries, flattening, leaping, or arching backwards as dodgeballs, jump ropes, and flying fists came at him. The school playground was a juvenile coliseum, where children used ropes as bullwhips, and fashioned a game of dodgeball into a gladiator event. Hordes gathered, circled, and aimed for the head 
shouting, "Think fast! arm back," blasting a crossfire of plastic balls. Some targets were hit in the back of the legs causing them to fall forward onto the blacktop. Luckier children were slammed, stung in the upper back, but managed to stay upright. Younger children yanked and tripped their peers as custom.

Scott must have identified with the thick-skinned and resolute creature The Thing. Like The Thing, Scott was a loyal friend, a defensive fighter, and tenacious. The Thing's deeper appeal came from a pathos of feeling like an outsider. Due to a physical deformity, The Thing felt gruesome among the dazzling blue-costumed entourage, The Fantastic Four. The Thing was further distanced from having a juvenile uncontrollable temper. The crusty gargantuan's underprivileged upbringing added to his suffering, yet his tender moments of reflection and regret humanized the monster.

Our mother was a borderline hysteric who lived in either disinterest or rage. Scott coped through a furious aggression, wrestling and punching schoolyard bullies, "Grab my hat again and I'll pound you!" which resulted in our mother's phone conversations with irate parents, visits with the principal, and paying for Keith Power's glasses.

Our Freon-cooled bodies grew clammy as we left the drugstore and mounted our bicycles. Bogards capped the top of a steep three-block hill, which now seems not so high. Our heavy framed cruisers were tough but luggish making the uphill trip brutal and the ride home dangerously fast. Parallel streets funneled downhill, like veins on my forearms leading to my wrists, to the elementary school. Sandwiched between palm and handlebar grip, the comic bags swung like pendulums as our fat rubber tires banged against potholes, coursed up and down driveways, and tore through intersections with the briefest of pause. We really peeled out, skimming sidewalks until the abrupt drop of the curb then coasting onto our front lawn. The boorish afternoon had crested, and the downhill breeze was a harbinger for a cool evening of cartwheels and catcalls on the front lawn or the occasional game of midnight tag.

My memories have a sensory quality to them. Dreary family dinners of pot roasts are leaden in my thoughts as rubbery lumps or old dry roots swimming in gelatinous broth; the patched asphalt of our street turned gooey by midday smelled of dinosaurs and tar pits; the feel of our comics, thin paper pamphlets were soft between our fingers becoming portals into other worlds. My mother seemed cheerless, vacuuming gray sour dust, breaking the backs of sheets, snapping them onto the beds, twisting wet laundry, wringing the juice from my childhood. My father was an unknown, silent and focused on something beyond. Both parents had brief moments of empathy coupled with erratic spells of uncontrollable anger. My mother was more consistent in her fury, my father silent until a tangential snap set him off.

One night at dinner my father, sitting at the head of the table, picked up his dinner spoon and began bending the bowl back and forth. His utensil was a Fred Flintstone spoon that we had gotten from box tops. I knew the four Flintstone spoons were weak. When I set the table, the Flintstones spoons seemed lighter and thinner that most of our silverware. My brothers were oblivious. My oldest brother was drinking his milk. I had never heard such loud swallowing.

I watched my father with his thumb and fingers griping the bowl, his fist smothering Fred, bending the spoon handle like a hinge faster and faster as the metal became warm and more pliable. My father was focused and quiet, and I am not sure he knew what he was doing. His eyes were looking beyond all of us, maybe at my mother's crystal glasses stored in the breakfront. I was not surprised to see the spoon ruined, the bowl curled flat to the spoon handle.

"Vincent!" my mother blared.

"What?" he seemed shocked, embarrassed, and then angry.

"Don't bend the silverware!"

"Ah, nuts." There was quick movement and then the spoon was thrown and my father gone.

Comics pulled us into simpler hair-raising dilemmas and ineffable solutions. We believed in the existence of our favorite heroes, that the paper and ink were less real than our hieratic characters. We held a surreal belief that these invented lives existed, and in the fiction of Thor, Archie, and Richie Rich, we imagined more truth than what we found in the volumes of our Encyclopedia Britannica. Of course, we knew that Susan Storm was not off somewhere turning invisible, but she transcended our lives of sarcasm, penny pinching, control, ultimatums, disinterest, and fear.

The Fantastic Four were superheroes that layered a preposterous family template on top of the quixotic 1960s nuclear family. Through parody, the Fantastic Four exposed contradictions of the nuclear family. Reed Richards, alias Mr. Fantastic, was overly protective of an indomitable wife, The Invisible Girl, who climbed into the rear of an atomic tank saying, "One invisible girl can sometimes accomplish more than a battalion!" (Lee \& Kirby, 1961b, p. 15). Susan Storm further mocked the traditional image of an incapable woman, flinging an alien across the room and saying, "Tsk! Tsk! Don't you know it's impolite to rush past a lady?" (Lee \& Kirby, 1961a, p. 12). True, Susan Storm was still The Invisible Girl despite being old enough to marry, to capture Skrulls, and to design crime-fighting costumes. And both the Fantastic Four and the nuclear family were stencils of thin sincerity and vague rhetoric. However, The Fantastic Four deconstructed traditional beliefs of the 1960s nuclear family through an edgy humor that Marvel comics were known for, giving Scott an inkling there was a way to get through this.

In the morning, we had finished our cold cereal by nine and were out the door as the temperature in the house began to climb. Our house was suffocating by lunchtime when my three brothers and I sat elbow-to-elbow at the kitchen table 
with shirts wet and pasted to our bodies. Our grim noon meals were endless bowls of burned canned soup only cooled by quick bites of saltine crackers. The table was ill-fitted for young children, and to reach the hot soup we sat with our legs folded under leaving our calves sore and embossed from the varnished hemp of the chair seats. As we leaned and balanced over salty boiling bowls of tomato bisque or chicken with rice, the scattered toast crumbs leftover from breakfast bit into my bare arms with the razor-like teeth of puppies.

The kitchen was cramped and swollen with school papers, letters, violets, soiled dishes, thawing meat, boxes of cereal, loaves of bread, scotch tape, jars of pencils, lists of weekly meals, columns of grocery items, newspapers, and a half dozen jars of my grandmother's jelly. My mother's lists were everywhere. There were envelopes covered in lists. Lists were written on the margins of the newspaper. The words on the lists changed little from week to week and seemed only revised versions of earlier lists. This all seemed an attempt for some order. The kitchen was a chaotic whirl of lost parent-permission slips, grocery coupons, renewal forms, recipe cards, sheets of to-dos. The kitchen had no fan, two windows, and little circulation. Our house sat snug next to our neighbors, and as we sat blowing on our lunch, we felt only the weakened sporadic breeze.

In the afternoons, we stretched out on the front lawn sinking deep into the sober unrelenting heat. Our chins tipped upward and behind our eyelids flashed a red movie featuring my mother live, screaming indecipherable tirades to an entrapped brother. When the shouting got too much, we mounted our bicycles to ride the three blocks up to Bogards Drugs, swerving to pedal under any tree canopy, believing shady parts of the sidewalk were cooler.

My earliest comics were the Sunday funnies that were read aloud by my father. He changed his voice at each word balloon, and Beetle Bailey, Nancy and Sluggo, and Prince Valliant became kind of real. Comics were about action, not telling. The stories became brief theatrical productions with my father playing all the roles, directing and providing sound effects. The combination of pictures and narration felt like an actual experience. We had not yet begun reading, but when we did, we still wanted our father to read aloud. The funnies performances were intimate and relaxed. Through his animated storytelling, my father had created a genuine relationship with the text. My brothers and I were transformed beyond personal pleasure. We had an experience seeing our father different. Through the voices of Beetle Bailey and Dagwood, our father explained himself. In his voice, we heard him interpret compassion, amazement, and curiosity. We heard him connect the lives of the comic characters first with his life and then with ours.

When I was eight, I began reading Little Lulu. Lulu was heroic and hilarious standing up to everyone-angry adults, robbers, bullies, and the supernatural — and Lulu used quickthinking pranks and alibis to get out of jams. I was impressed with Lulu's unflappable resourcefulness around adults. Her life seemed uncomplicated and within a few panels she had outwitted any antagonist. Poking fun at authority figures, like parents, truant officers, and the principal, Lulu's playful lack of intimidation was outrageous standing toe to toe with all comers. I would never attempt Lulu's schemes, but I learned to be quick at reading body language, how to tell a joke, and to disappear.

By fifth grade, I had become a private child who could tell a good joke. Memorizing lines controlled my social anxiety, and I learned timing from my Little Lulu comics, practicing punch lines to my bedroom mirror. Before the school day began, I performed brief riddles, anecdotes, one-liners to my teacher and then faded into my desk. Shrinking had some part in my detachment. I remember being desperate to fit in a smaller desk, to be a shorter classmate, to be overlooked. Whether by sheer will or genetics, I stayed small. Channel lock pliers were requested by my teachers every fall to lower my assigned desk. Loosening a center nut on a vertical pipe, the unlocked desktop slid down and was tightened.

Comics helped me to feel not alone. I began drawing my own comics, discovering the drawn line as a means to create my own reality. My pencil drew lives that were not frightened, crushed, or angry. The subject was families. I gave the graphite households names and ages, designed their homes and neighborhoods, drawing on lined notebook paper. I kept the portraits in a three-ringed faded blue binder under my bed. The nuclear family of the 1960s that seemed so perfect in Archie and Little Lulu comics was not my reality but what I longed for. I found comfort in these pencil people, believing I could be a part of a home where we laughed over dinner and kissed each other on soft cheeks. The façade of the 1960s nuclear family built from Dick and Jane primers, Wonder bread, kitchen nooks, and perky aproned mothers seemed sappy, but I ached for a semblance of predictability no matter how superficial.

My families needed homes that were functional. While visiting my cousins, I found a magazine rack in the living room filled with home-repair magazines. I flipped through pages marveling at the architectural symbols for windows, doorways, and stairways keen on the semicircles sweeping behind tiny drawn doors. Thanks to Popular Mechanics, my comic-book homes received entertainment walls, disappearing beds, push-button plumbing, soundproofing, built-ins, and houseboats in their driveways.

In 1953, Fredric Wertham's book The Seduction of the Innocent charged comic books with influencing America's children to develop psychosexual tendencies, fetishism, sadism, masochism, homoeroticism, and reading disabilities. A 1955 United States Senate subcommittee on Juvenile Delinquency recommended that comic book publishers adhere to a code of standards to protect their childhood audience. Fear of governmental established controls motivated the Association of Comic Book Publishers to form their own Comic Code Authority to regulate content and images. Consequently, vampires, werewolves, zombies, and 
ghouls were banned and the words horror or terror from titles. The word crime could not appear alone in the title. Love stories had to embrace the "sanctity of marriage" in their moral message and to avoid arousing "lower and baser emotions." Divorce should not be depicted as desirable. Law enforcement officials should not die as a result of criminal activity, and good must triumph over evil. Empathy could not be shown to criminals. The code had an insignia, resembling an S \& H Green Stamp, imprinted on the cover of comics free from gore, witchcraft, or any subject that seemed to challenge authority. Dr. Frederick Wertham dismissed the code as weak and ineffectual. Seven years later, I introduced Scott to Marvel.

We were at the Rock Island train station in Peoria, Illinois, with the entire family of aunts, uncles, and cousins to welcome the return of our maternal grandparents from Thailand. On a map, Thailand - shaped like the head of an elephant-was less exotic than the enormous black train engine that blew smoke and split ears with its whistle. Our grandparents were steady travelers and had been to Japan once already. There would be armloads of silk kimonos, hand-painted porcelain vases, and lacquered boxes with hidden compartments. I remember opening small pine boxes containing bald-headed geisha dolls with interchangeable wigs each wrapped delicately in tissue paper. The box lids had drawings of each chignon style, listing its translated name and social meaning.

The delayed arrival of the train left Scott and I wandering by the station newsstand where we were shocked to find bins of comic books.

"Hey Scott, what do you know, comics."

"Yeah, look, Popeye, Sea Hunt, Six Gun Heroes. Oh, Billy the Kid."

"Scott, oh, wow, you would like this."

On the wire rack was a comic featuring a green monster cracking up a city street. His head was enormous in comparison to the onlookers, and in his thick emerald fist he held a woman half normal and half a dotted outline. The three guys who were rescuing her were either flaming, made of orange rock, or had rubber band arms.

"These are so cool!" Scott was cradling the comic in his hands, studying the shiny graphic images. He peeled back the cover and was introduced to Dr. Reed Richards, Ben Grim, and Susan and Johnny Storm.

"I'm buying both of these," putting Marvel's Fantastic Four issue no. 4 with the Sub-Mariner and Spiderman issue no. 3 on the newsstand counter.

Scott became consumed with Marvel and an authority on Stan Lee, the editor and art director in the 1960s. "The Marvel Style" in which drawings lead the story, became epic. Traditionally, comics were text driven with illustrators filling in after the story was determined. However, beginning with Fantastic Four, Marvel's illustrator, Jack Kirby, used drawings to fuel the plot. Lee added dialogue and captions tailoring the writing to the art. Lee's dedication to working artists, the partnership of Kirby and Lee, and the belief that drawing can inform writing was a loved Marvel aesthetic.

Many Marvel fans were kids like Scott. Besides the knockout graphics, a charm of Marvel characters was their acknowledged human flaws. They had romantic problems, were antiheroes, got sinus attacks, acne, and sneezed while fighting. Once snooping through Scott's top drawer, I discovered an orange-colored sticker of The Thing pointing like Uncle Sam in recruitment posters. Across his chest "The MMMS - the Merry Marvel Marching Society-wants YOU!" commanded in black letters. Nothing else in his drawer was of interest, a cardboard egg carton filled with sockballs, a yoyo, a couple of Beatles cards, and a Marvel membership card. Years later, I learned the MMMS was big on college campuses. I was impressed and shocked that my nine-year-old brother had joined a national club and dumbfounded that he would know how to complete a form and mail it in. Until then, my brother's terrain had always been in my sightlines.

Every month a new species of superhero, the Incredible Hulk, Daredevil, Doctor Strange, Captain America, and Sub-Mariner, were introduced and if popular got their own series. Comics had a fast turnover at Bogard's, and there was no chance of back issues. Scott, as a Marvel fan, paid close attention to the abbreviation of the month in the upper left-hand corner of the comic. If he missed a new release, there was only the potential of less popular newsstands and none available by bike. Marvel fans clamored after early issues, and current issues sold fast. For past issues, the best opportunity was the Red Owl Grocery Store in northern Wisconsin near our vacation cabin.

Summit Lake, Wisconsin, included a laundromat, the Corner Café, a post office, few cabins, and a filling station. Continuing on Highway $\mathrm{T}$ for three miles you reach the cabin, one of fifteen skirting a small lake on the edge of a lumber camp. If the sun held, our world was a paradise of trails, swimming, and biking. The occasional hard rain meant errands to the Red Owl Grocery Store. The Red Owl was in Elcho, Wisconsin, ten miles from Summit Lake on Route 45. Elcho was a bit larger with an elementary school, the Red Owl, two gas stations, a post office, a restaurant, and a hardware store.

The Red Owl had floors of sawdust, aisles of sweatshirts, a toy shelf stocked with plastic-headed Native American dolls draped in tiny beaded necklaces and cellophane bags of plastic soldiers, and five wire racks packed with comic books.

"Look at this, a second issue of Hulk and an older Sergeant Rock and His Howling Commandos! They are all buried under all these Archies."

"Cool. How many do you have?"

"Sixteen"

"Sixteen?! You are buying sixteen comics? What is that? Three dollars?" 
"No, about two. No sweat."

"I'm just getting these Archies, two Little Lulus and a Beetle Bailey."

"Wow, look at this, Doctor Doom, look at this guy's armor plated body. Look at this face; its so gross; here's another issue with Victor von Doom as a college roommate of Reed Richards. Hey, in this one Doom is the secret ruler of this forbidden country. Crazy."

"Important events are both preceded and followed by ordinary real-life events" (Buber cited in Kepnes, 1992, p. 86). Picture a cutaway of the earth's continental crust: layers of granite, sedimentary, and metamorphic rock. Magma from the core pushes upwards and with enough molten gases interrupts tectonic plate boundaries. A mountain is formed or a volcano or a seamount, a big change. Yet, on either side of the fissure life goes on much as always.

One Sunday afternoon, when I was busy eating an Eskimo Pie at a family picnic, careful to unfold the silver wrapper without disturbing the chocolate coating, our maternal grandmother called a meeting to discuss the harmful influence of comic books. Our collections were getting sizable as we were throwing every extra cent into new series. My passion for Little Lulu had turned to Tales From the Crypt chock-full of secrecy, unpredictability, and darkness.

At the meeting, adult sentiment ranged from the uncles' indifference to my grandmother's panic. It had taken the "Cold War culture" (Menard, 2008, p. 124) ten years to reach the card tables of East Peoria, Illinois, where my grandmother gleaned information. My thought balloons were blank. My Cousin Mark claimed DC comics were good because they taught him science. Scott rolled his eyes adding, "I think comics make me a better reader. Vivian Hernandez and I are the best in our grade. Vivian came from Cuba to escape Castro. I must have read a thousand action comics." The decision was made that half of our comic books must be thrown out. Leaning back against the wall, I felt my spring-loaded barrette pop open. Picnic baskets were collected and filled with crusty-lipped casseroles. Station wagons were filled with families. Over the following weeks, we never were asked to fork over any comics. The eruption settled back to homeostaisis, and the lithosphere on either side was none the wiser.

\section{That Was Then, This Is Now}

I was spending the night at my brother's house in Chicago a few years ago and spotted Maus by Art Spiegelman on a bookshelf next to the guest bed. I shouted down the stairs. "Scott what is this?"

"Oh, that's something I picked up at a bookstore a year ago. The sequel, Maus II is there too. I think you would like it."

I began reading and was enthralled with the power of pictures and text to tell a story. Spiegelman's story about his father's experience in the Holocaust had emotional depth and richness in describing the particular. I soon learned about graphic novels, illustrated narratives that can take their authors seven years to express a viewpoint based on personal experience and through the storytelling to describe the complexity of a cultural group. Both comic books and graphic novels employ pictures and text, use a sequence of cells to reveal the plot, and have consistent characters. However, comics seem superficial with explanation marks a standard and a style so impersonal that dozens of illustrators and writers could recreate an issue.

"Only in theory do we begin to suspect the power of aesthetics to shape our lives," notes Tobias Wolff (2008, p. 71). Although comics are no longer enough for me, they gave me something at a time when I had little hope for escape. Adults-in-charge were stand-ins for my mercurial mother, and they were everywhere. I became very sensitive, braced for attacks. If I missed a facial sign or misjudged a situation, any sort of correction left me feeling in peril. I think for my brother and I, comic books eased the loss of irretrievable parents and were a comfort in our childhood. They did what art does, reminds us that we are not alone.

\section{Declaration of Conflicting Interests}

The author declared no potential conflicts of interest with respect to the authorship and/or publication of this article.

\section{Funding}

The author declared no financial support for the research and/or authorship of this article.

\section{References}

Hajdu, David. ( 2008) The ten cent plague: the great comic book scare and how it changed America. New York: Picador, 2008.

Kepnes, S. (1992). The text as thou. Bloomington: Indiana University Press.

Lee. S., \& Kirby, J. (1961a). The fantastic four fight back. The Fantastic Four, 2, 12.

Lee. S. \& Kirby, J. (1961b).The flame that died. The Fantastic Four, 3, 15.

Menand, L. (2008, March 31). The horror. New Yorker, 84, 124-128.

United States Senate Committee on the Judiciary. (1955). Comic books and juvenile delinquency (Interim report). Washington, DC: Government Printing Office.

Wolff, T. (2008). Winter light. New Yorker, 64, 70-71.

\section{Bio}

Vicky Grube $(\mathrm{PhD})$ is a professor of art education at Appalachian State University in North Carolina. She is the author of "Admitting Their Worlds: Reflections of a Teacher/Researcher on the Self-Initiated Art Making of Children" (2009), "Beyond Still Life: Collecting the World in Small Handfuls" (2008), and "Gulliver's Travels" (2004). She has an MFA in theatre arts and two NEA painting fellowships. 